\title{
A SCHIZOANALYTICAL PRAXIS FOR SOCIAL JUSTICE EDUCATION
}

\section{Delphi Carstens}

University of the Western Cape

carstensdelphi@gmail.com

\section{ABSTRACT}

This paper uses Deleuzoguattarian schizoanalysis to interrogate concepts of social justice in relation to the crisis of neo-liberal capitalism by referring to the work of the Situationist International movement, the posthuman philosophy of Giles Deleuze and Félix Guattari as well as Afrofuturism. Providing an array of new theoretical responses as well as pedagogical models that directly engage with social justice issues, Deleuze and Guattari offer an immanent model for a politics and pedagogy that is primarily concerned with becoming. I argue that finding new ways of dealing with the notion of change, or in terms of Deleuzoguattarian philosophy, becoming, is critical to making sense of contemporary concerns around issues of decolonisation as well as the move toward progressive transformation in education. This paper argues, furthermore, that addressing issues of social justice requires a type of shizoanalytical approach that is future-orientated and aligned with posthuman and not postmodern concerns. A schizoanalytical approach, as I will argue, intersects not only with critical posthumanism, but also with the new materialist and affective turns in current scholarship, drawing together varied environmental, political, and social concerns that pertain to the practice and scholarship of contemporary pedagogy in South Africa and elsewhere.

Keywords: Afrofuturism; capitalist realism; Deleuze; Guattari; posthumanism; schizoanalysis; situationism

\section{INTRODUCTION}

"One solution, revolution!" has become the rallying cry of various anti-capitalist protestors around the world. This sentiment, intersecting as it does with current student protest movements and calls for a decolonised education system, has led to ongoing trouble at universities. Gilles Deleuze and Félix Guattari's combined oeuvre offers a panacea, not only in terms of how to speak to the ongoing causes and conditions

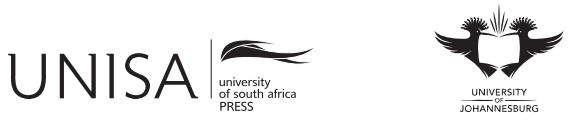


of protest, but also in terms of what to teach and how to teach it. Schizoanalysis, a manner of ontological pragmatics, is a term that I have used to broadly describe their theoretical programme. It describes a type of metamodeling that grafts a wide range of perspectives and models together in an experimental approach that recognises "sad" passions (such as paranoia, depression and schizophrenia) as "the potential bearers of new constellations of universes of values or reference" as well as sensorial, affective domains of possibility (Guattari 1995, 18). This approach, as I will argue, provides a wide range of perspectives for conceptualising and working with and through the capitalist malaise.

Our current pedagogical and institutional problems stem from the affective and material impacts of capitalism on socio-economic, political, and ecological realms. Since the beginning of the 20th century these issues have been conceptualised in relation to so-called contradictions in the social, economic and intellectual spheres. Deleuzoguattarian theory, as I will argue, presents ways for moving past the stifling problem of contradiction, which has resulted in a kind of poisonous circularity and pathology, not only amongst pedagogues and intellectuals, but also amongst social justice activists. Drawing analogies between Situationism, Deleuzoguattarian theory and Afrofuturism, I will investigate how a schizoanalytical perspective circumvents the problems of postmodernity and neo-liberal capitalism, speaking to "an audience yet to come" and thereby to a pedagogy of becoming. I will also consider why the schizoanalytical approach should be considered as posthuman rather than postmodern and also why, as Deleuze and Guattari remind us, we need to grapple with difficult knowledge and "sad" passions not only to enable clear thinking, but to produce a consistent relation to the future.

\section{FROM REVOLUTION TO SIMULATION: THE CHANGING LANDSCAPE OF CAPITALISM}

The Situationist International movement, formed in 1957, advocated détournement (a type of plagiarism, hijacking or re-routing involving intentional distortion to create new meaning) as well as dérives (random passages or "drifts") through the varied social ambiances of urban sensibility in order to galvanise both a realisation and a transformation of the social context of capitalism. They, as Roger Luckhurst writes, were the first to sense that the mood of late-capitalism was one of "ontological insecurity," a position they strove to exploit in an attempt to push the system to a breaking point by calling for spontaneity, malleability and decentralised nomadic thinking and acting (2005, 151). Beginning in 1966, the movement collaborated as poetic enragés (firebrands) with student protestors in a series of events that still resonate today. In an explosive and widely disseminated 1966 pamphlet entitled "Of Student Poverty" they wrote that capitalism demands "the mass production of students who are not [critically] educated and have been rendered incapable of thinking" and affirmed a revolutionary "creativity 
released in the making of history" (cited in Plant 1992, 95). The publication of two Situationist classics, Guy Debord's Society of the Spectacle and Raoul Vaneigem's The Revolution of Everyday Life in 1967 helped to further galvanise student and worker action, culminating in a series of violent disruptions, wildcat strikes and occupations whereby some twelve million protesting workers and students brought the economy of France to a virtual standstill in May 1968. The revolts had begun with high hopes for radical change, not only of the material conditions of workers, but also of the culture of intellectual impoverishment in the academies that protestors saw as complicit with the agendas of capitalism. Students took to the streets, rallying under the motto l'imagination au pouvoir! ("all power to the imagination!") - declaring a "situation" or "event" that Deleuze would later refer to as an "irruption of pure becoming" (1995, 144). Student and worker action was by no means confined to France, but "formed part of an ongoing wave of revolutionary action which spread across eastern and western Europe, South-east Asia and the United States" (Plant 1992, 96).

That these events happened at all, writes Sadie Plant, "showed that rebellion was still possible in spite of the sophisticated exercises of power effected within capitalist societies, valorising Situationist claims that subjective forces could overturn the logic of the commodity with the free play of desires, pleasures and created situations" (1992, 106). On the other hand these events, and others they subsequently inspired, failed to galvanise any lasting changes, due in no small part to the lack of clear agendas and excessive violence amongst protestors, political treachery as well as the failure of existing theoretical models for conceptualising the changes that were called for. Saskia Sassen writes that although social justice activism has, since May '68, "made progress in certain areas, such as in the extension of minority rights," little progress has been made in relation to grappling with and conceptualising the larger social inequalities and "expulsions" of neo-liberal capitalism $(2014,221)$. As Plant $(1992,106)$ observes: "In spite of the extraordinary uprisings against it, capitalist society has [proved] remarkably resistant to revolutionary upheaval."

While the Situationists might have disbanded in 1972, their influence has permeated contemporary philosophy (particularly that of Foucault, Lyotard and Deleuze and Guattari) as well as various autonomous networks of playful non-violent protest, resistance and subversion that continue to engage with "the central question thrown up by the failure of the May '68 events [,namely,] where, how and to what ends is power organised?" $(1992,117)$. Deleuze and Guattari are at pains to point out that revolutionary actions and theories fail in their fruitless attempts to search for and exploit oppositions in a capitalist system characterised by a radical "continuity of operations of self-re-establishment" (cited in Plant 1992, 133). As Deleuze and Guattari assert, "nothing ever died of contradictions," least of all capitalism (cited in Mackay and Avanessian 2014, 2). Deleuze and Guattari as well as numerous post-Situationist revolutionary collectives, such Radio Alice, the Autonomists and the Metropolitan Indians as well as the experimental university at Vincennes (where Deleuze taught 
alongside Lyotard and Foucault), rejected the dialectical thinking at the heart of Western knowledge production. They recognised that capitalism's continued violations of social justice required that entire systems of ideas and structures of knowledge themselves be transformed or reconceptualised. Instead of searching for radical oppositions and fundamental contradictions at the heart of social relations, these groups utilised the Situationist principle of détournement to scour amongst the remnants of variegated specialised theories, cultural practices and lived experiences in order to schizoanalytically construct new conceptual frameworks. Transcribing the Situationist concept of dérive to theory Lyotard in Libidinal Economy (1994), for instance, advocates a manner of drifting thought by which dialectical critique could be abandoned in favour of free-form conceptualisation. Deleuze and Guattari $(1988,422)$, meanwhile, formulated a "micropolitics of desire," breaking social relations down into an anarchic series of "desiring machines" that both produce and undermine the traditional identities and categories of social and political organisation, affirming the continued potential and relevance of revolutionary praxis:

The very conditions that make the state or the world war machine possible, in other words, constant capital (resources and equipment) and human variable capital, continually create unexpected possibilities for counterattack, unforeseen initiatives determining revolutionary, popular, minority, mutant machines.

For Deleuze and Guattari, writes Frederick Amrine (2012, 29), the failure of '68 amounted to a "failure of the [social and individual] imagination" to grapple with and conceptualise the true nature of the capitalist force-field, which had itself become remarkably flexible and untroubled by the complexities of contradiction. The 20th anniversary of May '68 brought home the point. The New Statesman, for instance, declared "in 1988 the revolution will be televised ... there'll be something for everybody," while an international bank packaged a series of adverts for student loans done up in the bricolage style of Situationist revolutionary pamphlets, offering "a range of services to help you handle your money, so that you can get on with your work while still enjoying student life" (cited in Plant 1992, 105). Rather than proclaim the obsolescence of a search for resistance and novelty under these new conditions, Deleuze and Guattari's schizoanalytical philosophical and pedagogical responses show that progressive change and social transformation are still very much possible under the banner of a posthuman ontology and epistemology that, as Amrine $(2012,29)$ writes, is genuinely "transformative and radical," accessing the imagination as a "living force" and source of vitality.

\section{POST 1968: CAPITALISM'S PERPETUAL INSTABILITIES}

Social justice has become a more complex issue in the decades following 1968, which have been marked by a gradual worsening in the totalising nature of capitalism as it 
progressively deregulated from state control. Its present radical neo-liberal free-market form is characterised by wholly new "predatory formations" mobilised through a "systemic mixture" of Gordian financial innovations, complex technological capacities for resource extraction and social control as well as artful government/corporate enablements (Sassen 2014, 13). As Mark Fisher writes, "flexibility, nomadism, spontaneity ... decentralised thinking"- the very hallmarks of Situationist agitation and liberal communism - have come to "constitute the dominant ideology of capitalism today" $(2009,28)$. This "deployment of complex forms of knowledge and creativity" has brought "robust corporate profits" but also "astoundingly elementary brutalities ... [including] a global scale-up of environmental destruction, which is currently booming back across the world" (Sassen 2014, 220-21). The principle of continuous economic growth hides the "shrunken economies" in much of the developing (and even in parts of the developed) world, the rise of new voracious classes of monied elites, endemic unemployment and poverty, mass migrations, "the proliferations of dead land and dead water"; all of which mark capitalism's new mode of "toxic development" and its "dynamics of social and environmental expulsion" $(2014,222)$.

Contrary to the stark realities on the ground, many economists persist in believing that we have attained a type of capitalist "utopia," writes Krishan Kumar $(1995,207)$. In the words of Francis Fukuyama, the new order of global capitalism is a world in which "daring, courage, imagination, and idealism [have been] replaced by economic calculation, the endless solving of technical problems ... and the satisfaction of consumer demands ... [in which] there can be neither [new] art nor [new] philosophy" (cited in Kumar 1995, 207). To paraphrase Jeanette Winterson $(2007,136)$, in this new world order, "if you can't buy it, spend it, trade it or develop it, it doesn't exist." "Commercial profit-making" has been pushed to "the innermost boundaries of subjectivity itself," writes Rosi Braidotti (2006a, 3), "making 'I shop therefore I am' the leading refrain of our times." Even in higher education, as Fisher writes, students are no longer the "subjects of disciplinary institutions" or even the locus of effectual resistance and cultural novelty, but simply "the consumers of services" $(2009,22)$.

Something more sinister than the death of the utopian imagination, however, seems to be happening as state-run social services around the world are progressively dismantled. In these new conditions, even higher education no longer offers a dependable means of social upliftment. Broadly speaking, most students no longer have meaningful or even guaranteed job prospects to look forward to post-university, writes Fisher $(2009,26)$ : "Pay for your own exploitation, the logic insists - get into [student] debt so you can get the same McJob you could have walked into if you'd left school at sixteen." It seems moreover, writes Fisher, that "an invisible plague of psychiatric and affective disorders" has spread along with post-Fordist economics, engendering a widespread mental distress amongst all sectors of society, rich and poor, included and excluded alike, that mirrors capital's own bi-polar "lurching between hyped-up mania and depressive come-down" $(2009,35)$. The "schizophrenic double pull" that Deleuze and Guattari identify in the 
workings of capitalism express, as Braidotti writes, a "conflict between, on the one hand, the rising demands for subjective singularities, or autonomy and, on the other hand, the conservative re-territorialization of desires for the purpose of commercial profit" $(2006 \mathrm{a}, 3)$. Hence the need for a schizoanalytical perspective that can, as it canvasses across multiple modalities and specialised knowledge production systems for new meanings and constellations of affect, beat capitalism at its own desiring game.

There is a pressing need for new conceptual tools or weapons. The contemporary experience of capitalism has become something more than mere bi-polar lurching between boom and bust, autonomy and enslavement. It has become the very experience of calamity itself - an affective force-field that transcends mounting debts, collapsing families and job insecurities. Capitalism, as Kumar writes, "is seen to threaten the very life-support systems of the planet ... left unchecked it bids fair to turn the world into a moral and material wasteland" $(1995,208)$. Rising incidences of environmental catastrophe, political disaster and social violence, notes Slavoj Žižek, betray a mounting existential crisis, a sense of "meaningless intrusion [by] a destructive rage which has no clear cause" $(2011,430)$. "The accident has [today] become the ordinary," opines Paul Virilio, speculating that contemporary history is "a spectacle of velocity in ruins" (cited in Kroker 1992, 33). Economic, social and environmental chaos loom as the costs (and side-effects) of industrial production, corporate power-games, endemic corruption and mass consumerism continue to climb exponentially. This, in any event, is the future that is broadcast through global entertainment networks where catastrophe and acts of meaningless violence are standard fare. The contemporary world has been turned on its head reasons Virilio, citing increasingly destabilised social, ecological, and technological side-effects as causes underlying the postmodern failure of the cultural imagination and the subsequent "implosion of history" $(1992,33)$. The economist Alvin Toffler used the term "future-shock" to explain the socio-cultural trauma caused by the transition from manufacturing-based post-war "social capitalism" into deregulated post-industrial neo-liberalism. As I have noted, more than social trauma is being signalled by the new social and environmental realities. Rather, what we appear to be witnessing is not only an alarming dearth of cultural imagination, but perhaps the very death of the future itself. As Fredric Jameson $(2007,1999)$ bleakly observes, "it is easier [today] to imagine the end of the world than the end of capitalism." There is something distinctively postmodern about this scenario. The exponential spread of global mass media and pop-culture in the "informational age" has spawned what Felipe Fernández-Armesto refers to in Civilizations (2001) as "the triumph of bad news" and the widely perceived "failure of progress" - an "erosion of confidence in the future" amongst postmodern academics and intellectuals (2001, 543-44). Under the disposition of postmodern theorising, writes Fisher, "the slogan which [best] sums up the new conditions is "no long term"' $(2009,32)$. 


\section{WHY POSTMODERNISM NEEDS DITCHING}

Inspired by Deleuzoguattarian praxis and the Situationist faith in intervention, the arrival on the contemporary scene of an array of posthumanist and new materialist philosophies appears to signal that a progressive transformation is perhaps finally under way. Postmodernism, like modernism before it, appears to no longer be the main guard, but the rear guard, its methodologies thoroughly institutionalised and its thinkers no longer challenging the status quo in any meaningful sense. In fact, postmodernism appears to have entrenched itself somewhat more ominously than any of its predecessors in the contemporary real. "It has established itself as a social condition with neither history or direction," writes Plant, adding sarcastically that "demands for a suicide [of postmodernism] would be tantamount to asking the entire world to disappear, and not just apparently" $(1992,182)$. Clearly we are not out of the postmodern woods yet. As Rosi Braidotti $(2006 \mathrm{~b}, 1)$ observes, some of postmodernism's most insidious conceptual and cultural habits - its denial of the future, its celebrations of the "inorganic, the sublimely fake and the purposefully inauthentic" - are still very much with us. Postmodernism, as Braidotti (2006b, 1) observes, has produced things like "feminism without women," racism without race, "natural laws without nature," animals without animality and sexuality without gender. Meanwhile neo-liberal capitalism, which postmodernity mirrors, has produced economic growth without development, colonialism without the colony, an ever-widening gap of inequality between haves and have-nots and, most alarmingly, an ongoing 6th mass extinction of biological life that could result in the extinction of the human race itself (Jones 2009).

The political economy of bio-technological capitalism "multiplies and distributes "differences' for the sake of profit" while unhinging the "dialectical bond" between "otherness" and the "processes of its discursive formation" (Braidotti 2006b, 1). These are compelling reasons to search for alternative ways of thinking and doing. As Jussi Parikka $(2015,6)$ has observed we desperately need "new vocabularies" to address our precariously mediated global reality, new vocabularies that postmodernity has failed to supply. What Parikka puns as the "Anthro-obscene" $(2015,7)$ gestures towards industrial capitalism's apocalyptic inauguration of the geological "age of man" as well as postmodernity's simultaneous celebration of "conceptual immateriality," while pointing directly at the thoroughly ignored dimension of our "technical materiality." At stake is a troubling conceptual blindness or indifference to the toxic relationality between humans and a multitude of trampled animal/plant others that are co-imbricated with us in an obscene garbage-strewn world of toxic wastefulness and worsening social/ environmental expulsions.

Jameson speaks of postmodernism circling around the gyre of an eternally repeating ever-present, devoid of future or past $(2007,281)$. For many contemporary theorists working outside of postmodernity's ambit this circularity belies its total complicity with commodity capitalism. Here we might need to pay attention, for a moment, to one of the foremost intellectual figures of postmodernity, Jean Baudrillard, who 
claims, in typical postmodern fashion, that there can be no more new moves in the game. Hyperreal capitalism, he writes, recoups all gestures as soon as they are made. Moreover, revolutionaries, artists and writers "can parody this world [of the media spectacle], illustrate it, simulate it, alter it [but] never disturb the order, which is also [their] own" (Baudrillard 1994, 110). Unable to challenge the dominant paradigms of linguistic mediation, "with its twin forces of representation and interpretation, which have dominated our images of what it means to be a subject," even postmodern linguistic theory has cemented itself in an outdated circular loop of human-centred ways of thinking and doing, writes Braidotti (2006b, 1). As I have already observed, postmodernism seems to have ushered in a rather disturbing form of indolent catastrophism. The sense that one ultimately gets from its theorists, writes Christopher Palmer $(1999,78)$, is that "one can play, purchase, enjoy, and indulge but not make the slightest difference."

Nevertheless, as Plant observes, "networks of subversion continue to arise in even the most postmodern pockets of the postmodern world" $(1992,176)$. Aside from the new theoretical instruments (such as schizoanalysis) supplied by posthumanism and the new materialisms, there are other signs of a changing landscape too. Despite their manifest shortcomings and failures, the Arab Spring and the ongoing student protests, both in South Africa and abroad, have highlighted that a type of Situationist détournement is not only possible but inevitable - this time involving the very locus of neo-liberal capitalist power-relations, communications and information media. These and other countercultural groups have recognised, as Manuel Castells $(2010,49)$ writes, that "resistance to [the capitalist] power programmed in the networks" will and can, from hence forth, take place only "through and by networks" that are themselves "powered by information and communication technologies" (2010, 49). Indeed, Situationist revolutionising is still alive: "détournements, subversions, and irreverent reroutings continue to match the assimilations, dissipations and recuperations which strengthen capitalist society" (Plant 1992, 183). Science fiction writer Bruce Sterling (1986, x) points out that young people today believe that "traditional power structures [and] traditional institutions, have lost control of the pace of change." This, of course, includes universities. Four decades ago already the self-educated "geek" countercultural hacker movement, to which Sterling was affiliated, mobilised around the transformative potentials of information technologies. For them, as for protest movements today, "a new alliance was becoming evident: an integration of technology and counterculture. An unholy alliance of the technical world and the world of organised dissent - the underground world of pop-culture, visionary fluidity, and street level anarchy" (Sterling 1986, x). The Situationist spirit of insurrection, formulated around the ethos of staging counter-spectacles, is still very much alive. So too is Deleuzoguattarian "rhizomatic" schizoanalysis with its organic model of social organisation and community cooperation. Contemporary examples, such as the Afrofuturist collective, Complex Movements, to whom I will return presently, utilise immersive audio-visual environments and emergence theory to stage situations along these lines. Counter-cultural projects such 
as these are, like the capitalist force-fields they are opposed to, "interconnected through decentralized networks and webs" (Kiley 2015, 1).

\section{HYBRID/SCHIZOID POSTHUMAN MACHINES}

Deleuzoguattarian "machines" have been used as metaphors for the uncanny agency of advanced technologies, particularly to indicate their insurgent potential for dissolving the certainties of anthropocentric identity. Similarly, the related concept of the rhizome has been appropriated to figure the Internet and the attendant notion of schizoanalysis taken to represent an array of identity re-coding strategies relevant to the age of information. That there continue to be numerous uncanny assimilations between Deleuzogauttarian machines and the "hertzian" machines of postmodernity in contemporary posthuman theory is hardly surprising. As Sterling (1986, xi) observes, information technologies are clearly "visceral ... pervasive, utterly intimate ... redefining the nature of humanity, of the self ... [full] of frighteningly radical potential." There is an uncanniness attached to this perverse intimacy. As Anthony Dunne $(2005,107)$ writes:

Electronic objects are ... machines with extended visible skins. ... They couple and decouple with our bodies without us knowing. Working on microscopic scales, often pathogenic, many electromagnetic fields interfere with the cellular structure of the body. Paranoia and horror accompanies dealing with such hertzian machines. How do they touch us? Do they merely reflect off our skin, or the surface of our internal organs?

For posthumanists this uncanny adjacency of human and machine has a potentially productive function. Braidotti $(2006 \mathrm{a}, 1)$ explains that for contemporary posthumanism "technology remains at the heart of a process of blurring fundamental categorical divides between self and other; a sort of heteroglossia of the species, a colossal hybridisation which combines cyborgs, monsters, insects and machines into a powerfully posthuman approach to what we used to call 'the embodied subject."' Indeed, in Deleuzoguattarian praxes, she explains (2006b, 1), "signals replace signs, expression replaces representation and codes replace interpretation." The machinic, the rhizomatic and the schizoanalytical do not therefore express, in Lacanian fashion, the personal, the subjective, the androcentric or even the anthropomorphic. Instead, the schizoid and machinic "expres[s] the impersonal, or intra-personal intensive resonances between the multiple levels of inter-connections that make [all] living beings [and not just humans] tick" (2006b, 1). As Parikka has pointed out in The Geology of Media (2015), it is not only the human "self" that has been transformed by communications devices and the mining and industrial processes to which they are affiliated, but entire "machinic assemblages" of societies, ecosystems and affective human/non-human relations. These are boundary-dissolving, uncanny, machinic entanglements that unpick anthropocentric and anthro-obscenic certainties and that require further exploration in classrooms and not just in posthuman theorising. The machinic engages an uncanny relationality that confronts us with "a strangeness given to dissolving all assurances about [stable] 
identity," writes Nicolas Royle $(2003,9)$. This kind of "uncertainty," if used well has, as Ronald Barnett writes, a distinctive pedagogical function, opening "unfamiliar spaces" for learning and encouraging us "to come into new modes of being" $(2007,1)$.

\section{WHY SOCIAL JUSTICE PEDAGOGY NEEDS SF}

The Situationists, according to Martin Coverley, "saw their explorations at least partly as preliminary to the production of some kind of new space" $(2010,136)$. Inspired by this ethos, Deleuze and Guattari have attempted in their own theorising, to think beyond apparent contradictions, to create impetus for new social actions and individuations, to reach for new "weapons" to wield against all that conserves and restricts, to galvanise new situations that reach forward into the future. Their term "line of flight" is used to describe an instance whereby the darkness of schizophrenic madness and paranoia (a mirror of the affective and mental disorders of capitalism) can be inverted and potentiated, becoming a space from which to perceive the light of a future becoming. From social forms, write Deleuze and Guattari, capitalism's line of flight - in fact, any line of flight - "tears away particles, among which there are now only relationships of speed and slowness, and from subjects it tears away affects" $(1983,81)$. This, then, is the movement that individual and social collectives of resistance themselves must take. They continue (Deleuze and Guattari 1983, 91-2):

Far from being a flight outside the social, or from being utopian or even ideological, these lines [of flight] actually constitute the social field, tracing its shapes and its borders, its entire state of becoming. Basically, a Marxist is recognized by his assertion that a society contradicts itself, that it is defined by its contradictions. We say rather that in a society everything flees, and that a society is defined by its lines of flight, which affect masses of every kind (once again, "mass" is a molecular notion). A society, or any collective arrangement, is defined first by its points of flows of deterritorialisation. History's greatest adventures are lines of flight. ... It's always along a line of flight that we create because there we are tracing the real and composing a plane of consistency, not simply imagining or dreaming. Flee, but while fleeing, pick up a weapon.

In Exclusions (2014), Sassen draws attention to the urgency of radical new ways of conceptualising with and through capitalism, such as the schizoanalytical project. The "subterranean effects" and affects of neo-liberal capitalism are "cutting across familiar conceptual and historical ways of analysing," she writes $(2014,217)$, rendering them wholly incapable of describing and understanding the new causes, conditions and impacts of capitalism on societies and environments. My argument here is that the Deleuzoguattarian enterprise offers one very effective way of mapping and subverting the schizophrenic line of capitalism's flight, which has increasingly come to rely, as Sassen $(2014,12)$ writes, on complex new technologies and esoteric financial instruments to expand its capacities for resource extraction, environmental devastation and socio-economic exclusions. In doing so, we might forge new conceptual and affective weapons while formulating lines of flight that lead us away from catastrophe. 
The Deleuzoguattarian idea, as the Orphan Drift posthuman audio-visual collective writes, is to rethink our understanding of social, environmental, technological and economic relations in order to "mobilise somatic/affective voyages into transformative recoding practices" $(1995,229)$. As Steve Goodman writes of Afrofuturistic "sonic" collectives such as Underground Resistance, "feeling around in the dark, in the toxic smog of megalopian pressure, when no hope seems to exist, when no [socio-economic] stability persists, rhythmic decisions [can] still get made, collectives mobilised and potential futures produced" $(2010,192)$.

Deleuze and Guattari are well aware, as Fisher observes, that there are revolutionary affective and vitalistic ideas that erode capitalist, anthropocentric and androcentric reality constructions, fictions and "abstract infectious vectors that operate against [imposed and regimented] identity and subjectivity" (2001, 231). Science fiction or speculative fabulation (sf), when used properly, is one such vector. Sf has been used very effectively by Afrofuturist writers, artists, activists and collectives as a means of not only envisioning radical new worlds but also for working towards radical social and environmental justice transformation in the present. As activist Walidah Imarisha writes, "for all of its ability to analyze and critique, the [postmodern] left has become rooted in what is ... forgetting what could [in the future] be" $(2015,1)$. She continues by quoting sf author Ursula Le Guin who at a recent awards ceremony urged the audience to resist the seemingly "inescapable power of capitalism" by learning the most valuable lesson of history: that "any human power can be resisted and changed by human beings" (Imarisha 2015, 1). From Le Guin's perspective, writes Imarisha, sf enables us to envision "possibilities outside of what currently exists ... which is precisely why social justice movements need sf" $(2015,1)$. Author Adrienne Maree Brown adds that Afrofuturism embraces forward-thinking socially-conscious sf that doesn't remain neutral but has "change and societal transformation" as its goal, speaking directly to those who have been marginalised, and "showing change from the bottom up rather than the top down" (Brown and Imarisha 2015, 279).

This an ethos that the Detroit-based Afrofuturist collective Complex Movements takes to heart. Their latest project Beware of the Dandelions - part performance, part workshop and part audio-visual installation - combines a Situationist praxis with sf narratives, sonic fiction and complex digital platforms to transform local community injustice stories into an interactive futuristic parable in which the audience "participates as post-apocalyptic survivors" (Meek 2016, 1). Touring through various urban centres in the US, the project constantly morphs its sf narratives and audio-visual displays via creative exchanges with audience members as well as local social justice activist groups (Meek 2016). Using performers and technological devices that are carefully concealed from view, Dandelions tells a sf parable through spoken word, video-mapped visuals and Afrofuturist electronic music. Audience members are invited to experience "the future history of a parallel world" inside an enclosed "400 square foot polyhedron Pod structure" onto which visuals, music and spoken word are externally projected 
by occluded disc-jockeys (djs), mic controllers (mcs) and visual jockeys (vjs) (Fintoni 2016, 1). This is clearly a Situationist inspired détournement of the magic-lantern show or "phantasmagoria" (a 19th century forerunner of contemporary cinema) which, as Carolyn Evans writes, utilised "backlit optical illusions," always hidden from view, as a form of "dramatic deception or display" $(2003,89)$. The social critic Theodor Adorno, continues Evans, used phantasmagoria as a metaphor to "designate the tricks, deceits and illusions of capitalism, with its sleights of hand" that uses fear and paranoia about invisible mechanisms and forces to manipulate and create "false desires" (2003, 89). Since the phantasmagoria's light and sound sources were always hidden from the audience, this device provided Adorno "with a metaphor for the way in which the working mechanisms of capitalist production are hidden from view" to divert the attention of the public, via mediated spectacle, from the carefully manipulated excesses of consumption, control and exclusion $(2003,90)$.

Dandelions exploits the language of phantasmagoric invisible deception, via claustrophobic enclosure, bombardment with visual stimulation, as well as the paranoia and fear that accompany "schizophony" (sounds without perceivable sources). Unlike the original phantasmagoria, or even contemporary mediated entertainments, which cultivate passivity, Dandelions' performers and the audience are engaged in an active conversation. Based on carefully monitored audience responses and moods as well as nuanced collaborations with local activist groups, the occluded mcs, djs and vjs continuously adapt the performative content in order that together "a new chapter of the story may be spontaneously revealed" (Fintoni 2015). The intention is not only passively therapeutic but also proactively so: To get audience members to think about and sensually participate in complex co-imbricated social, economic, environmental and technologically-mediated entanglements as well as to "mobilise around and co-create" new potential futures $(2015,1)$. This kind of therapeutic mapping is schizoanalytical. It is, as Guattari explains, "a metamodelization [that] tries to get you to understand how it is that you got where you are? What is your model to you? It does not work? - Then, I don't know, one tries to work [differently] together. One must see if one can make a graft of other models" $(1995,133)$.

In Cinema II: The Time Image (2013), Deleuze describes the work of avantgarde film-makers who, like Complex Movements, employ occlusions, glitches, discontinuities and displacements of spatio-temporal registers as a means for revealing radically novel potentials and possibilities and thereby restoring our confidence in the world. As Joshua Ramey explains, for Deleuze, experimental countercultural cinema works with a Spinozist sense of ethics grounded in a sense of what bodies can do. Freed from stereotypical plots and predictable patterns of emotional tension and release, the "aberrations and discontinuities" of avant-garde cinema, "may be therapeutic to the extent that they can condition the brain and the body to endure a more profound existence, one that is closer to the multiplicity of discontinuous durations of which life is composed" $(2012,150)$. Projects such as Beware of the Dandelions, through 
science fictional audio-visual experimentation, perform détournements that not only draw attention to the insidious impact of mediated capitalism on bodies, brains and local communities, but also enact a kind of psychic healing. The impact of such a jarring but potentially illuminating counter-spectacle, argues Ramey, paraphrasing Deleuze, has the effect of restoring "a faith that the traumatic and fateful character of events and their effects upon our lives are not irreversible and may be subject to intervention" (2012, 151).

There is something radically transformative about sf that asks us to consider the playing out of changes in the social world, writes Afro-American queer activist Nona Cipri, asking that we extend the initiatives of groups like Complex Movements to include not only the global socius, but also to embrace a pragmatism about the difficulties of creating and sustaining transformation $(2015,1)$. Writers of Afrofuturistic sf such as Octavia E. Butler, she continues, "never shirked from showing the dirty, dragging work of creating change" $(2015,1)$. Butler's gritty sf-especially in her Patternist and Xenogenesis series - depict change as a discontinuous, slow, and jarring process of tireless engagements with sacrifice and confrontations, often psychically violent, with difficult knowledge and sad passions. Demanding harrowing rites of passage, her uncanny futures are accessible only to those who are "already at home in disaffecting lifeworlds," who consider themselves already "alien" or "radically outside," to those already at ease with the necessity of eco-socialist perspectives that demand symbiotic allegiances with a multitude of non-human others (Gains and Segade 2008, 146). To help us grapple with these concepts, Brian Massumi (2014) suggests an affective and vitalistic politics of animality that may help us to go beyond the limits of anthropocentric social construction, to think the formerly unthinkable.

\section{OPENING UP SPACES OF RADICAL POSSIBILITY: SCHIZOANALYSIS AS A POSTHUMAN NAVIGATIONAL TOOL}

Chandra Talpade Mohanti writes that decolonisation is not only about finding new ways of knowing, being and seeing outside of standard Western social and ontological constructs, but also about a revisioning project that extends beyond "conceptions of individual identity and state government" $(2003,8)$. Openly critical of the Lacanian linguistic paradigms of mediation and subjectivity, and of much of Western philosophy's dominant paradigms besides, Deleuze and Guattari's schizoanalytical model seems to segue with Mohanti's vision. Their project offers a way of thinking beyond the limits of constructed identity as well as the poisoned affects resulting from the deregulations and expulsions of capitalism. Their rhizomatic project, moreover, asks us to reconceptualise existing knowledge in new and exciting ways, encompassing an espousal of "schizophrenic" mind-states that can accommodate numerous possibilities 
simultaneously, form novel alignments, entertain "crazy wisdoms" and transverse wildly across and between multiple subjectivities, vectors and fields:

A rhizome has no beginning or end, but is always in the middle, between things, interbeing, intermezzo ... The rhizome is alliance, uniquely alliance ... the fabric of the rhizome is the conjunction, "and ... and ... and." This conjunction carries enough force to shake and uproot the verb "to be" ... to establish a logic of the AND, overthrow ontology, do away with foundations, nullify endings and beginnings. (Deleuze and Guattari 1988, 25)

By thinking rhizomatically or schizoanalytically, we can begin to re-think convergences of abstraction, complexity, globality, technology and affect as well as (inter)subjectivities in terms of becomings and, proceeding from there, map "events," and points of contact/ contract as well as (to borrow from the language of chemistry) "phase changes" or "points of bifurcation," and (borrowing from classical and quantum physics) "diffractions," where the behaviour of groups, individuals or materials change (sometimes radically) in response to the presence of "attractors," events or ambiences. To risk overstating the point, in such a mapping of (inter)subjectivities and new identities we, as posthuman schizoanalytical cartographers, must take especial care to move toward a schizoanalytical understanding of non-dominating, becoming interrelationships that remain open to multiplicities, materialities and non-human meshworks. These are all crucial considerations, as I argue, that need to be taken on-board in our pedagogies if we wish not only to get to the bottom of the ongoing student malaise, but also to reconceptualise the co-imbricated issues of social and environmental justice.

Schizoanalysis promotes a nomadic subjectivity as a means for galvanising social action as well as for creating a pedagogy for a people to come. Amongst the many examples Deleuze and Guattari use to explain their schizoanalytic "nomadology" is the example of the "iteneracy" of the "shaman-smiths" of the Eurasian steppes and of West Africa. The shaman-smiths, they write, invented "holey space" to practice their secret craft, interweaving "sedentaries ... nomads (and others besides)" in a complex mesh of social and material relations that connected empires, kingdoms, nomadic tribes and transhumant forest dwellers, mobile workshops, centres of learning and vast trading networks $(1988,415)$. Whereas the "striated space" of empire builders and kingdoms refers to the "territorialised," consolidated, departmentalised and compartmentalised knowledge-production systems of the "state," "smooth space" relates to the aggressively creative, deterritorialised and heterogeneous space of the nomad insurrectionists. The "nomadology" of smiths, which Deleuze and Guattari conceive of as a potential political and pedagogical "weapon" or "war-machine" for creating new forms of social and individual expression is not, however, entirely smooth (or deterritorialised). Instead it is hybrid and holey, "connecting with both smooth and striated space" as it tracks possibility space towards new destinies and arrangements $(1988,415)$.

Schizoanalytical thinking favours a conjunctive instead of a disjunctive approach, emphasising "inclusiveness, flexibility, mutability and multiplicity, acknowledging the entangled kinships between humans and a multitude of non-human others" (Carstens 
2016, 255). To this we might add the project of seeking out entangled exchanges and searches for potentially productive cross-overs between different cultural ways of doing, seeing and becoming. In reclaiming our desires from the expulsions and affective disorders of postmodern capitalism and in finding new ways of expressing and socially enacting empowering alternatives, we need also to urgently "stress a rigorous vision of affectivity" and a "vitalist ethics," writes Braidotti (2006a, 4). Schizoanalysis asks that we don't entirely dismantle existing fields of knowledge but rather that we make them holey, drilling them full of openings and paths of exchange, encouraging exchanges with other disciplines and cultural ways of knowing in order to form a dynamic body of knowledge that is both experimental and diffractive.

The specific fields of knowledge in which we as pedagogues often operate are not isolated, distinct, stand-alone entities. "Rather, they exist in a thick fabric of lateral relations, associations, and chains of actions between material things, larger environments, individuals, and collective actions, connecting different physical scales and spheres of action" (Lahoud and Weisman 2014, 1). Rebecca Solnit $(2008,2)$ continues on this line of flight, writing that what's now urgently needed in pedagogy is "more scope, more nuance, more inclusion of the crucial details and associations" that single-discipline conventional knowledge systems have frequently excluded. Invoking the metaphor of walking, Solnit explains that "if fields of expertise can be imagined as real fields, fenced off and carefully tilled, then a process of walking takes a path that trespasses through a dozen fields." What we desperately need now, she continues, are "unfenced lines of inquiry" $(2008,2)$.

\section{CONCLUSION: WHERE THE TROUBLE IS AT TODAY}

In The Three Ecologies (2000) as well as in Chaosmosis (1995), Guattari argues that we are being mentally manipulated through the production of a collective, mass-media subjectivity. Deleuze and Guattari together conclude What Is Philosophy? (2009) with a similar conundrum. That there might be a need for a new mental ecology to combat this mass psychosis is an idea that pervades their work, both separately and together. Guattari (2000) argues, for instance, that individuals are captured by their environments, by ideas, tastes, models, ways of being that are constantly injected into them. It is a question, he believes, of making pragmatic therapeutic interventions in the minds of students in order to facilitate an escape from a "capitalist realism" that has engendered depression, paranoia and anxiety. When dealing with these affective disorders, writes Guattari (1995), the goal is to deterritorialise the mind from the hardening or territorialising nature of depression that fixes us in despair. It is a question of "a production sui generis," of hijacking the "diverse possibilities" that the mental ailments of capitalism offer us "for recomposing existential corporeality," for escaping "repetitive impasses" and for "resingularisation" (1995, 6-7). There is much for pedagogues to learn from Afrofuturist sf and from Situationist-inspired groups like Complex Movements that perform similar therapeutic acts of imaginative action. Like 
the science-fictional theory-fictions of Deleuze and Guattari, the sf enacted by these and other diverse groups, such as 0rphan Drift, offer protocols for experimentations by which we might extend our minds and affective capacities as well as our teaching into novel territories of becoming. Our goal as pedagogues must be, as Franco "Bifo" Berardi writes, to create "social zones of resistance [and] therapeutic contagion" (2009, 220). To cultivate dissident rather than consensual subjectivities of like-mindedness we need to move toward experimental modes of being and becoming rather than fixed and stratified modes of thought. Using sf as a basis, we may attempt to cultivate a will to learn amid uncertainty and to open up new fields of virtuality - affective, aesthetic and intellectual capacities - in the minds of our students. Yet, as Deleuze and Guattari frequently caution, cultivating dissensus does not imply that we shouldn't rally, in our dissident subjectivities, around common causes. Anthropocentric thought and its main driver today - capitalist realism - have become so ubiquitous, so deleterious and so apparent that no strata of the socius, no individual, no animal or ecosystem is immune. We desperately need to make a common cause in the environment as a way of effecting social justice and turn it into a radical force in the world. Guattari (2000) emphasises that, first and foremost, we urgently need to mobilise around the uncanny spectre of ecocide. It is a fact, after all, that the "event" of capitalism has engendered a mass extinction. Not only does this imply that we can no longer remain captivated by our alltoo-human human subjectivities but it also means that we urgently need to cultivate a radical "outside" to anthropocentric thought. Rick Dolphijn (2015) sums up Guattari's thinking thusly: "we should not open ourselves up to the world, as Derrida would have it, [rather] we should allow the world to open us up."

Douglas Kellner and Stephen Best $(1991,108)$ have critiqued Deleuzoguattarian praxis for formulating intersubjectivity (or "group" subjectivities) in relation to "abstractions" involving "imbricated machinic and criss-crossing rhizomatic lines." There are, however, compelling reasons for formulating contemporary subjectivities and intersubjectivities along the lines of such "abstractions." As Guattari (1984) has pointed out, under the aegis of capitalist power-relations, the "shares" in subjectivity are never equally determined, but differ radically depending on whether one is a man, a woman, a member of a minority or majority, poor, rich, etc. The moment an "I-ego" identity formulation is brought into operation, he writes, then individual or group identities/intersubjectivities become radically "overdetermined" by whole sets of "social stratifications, hierarchical positions and power relationships" (Guattari 1984, 143). To help us conceptualise these multiplex relations, Deleuzoguattarian praxis provides an uncannily familiar folding concept - that of affect. As Tim Ingold (2011) explains it, Deleuzoguattarian machinic, rhizomatic and schizoid modalities enable us to go beyond the "I-ego" by aligning with the animist and egalitarian modalities of "primitive" egalitarian societies by which agency is attributed not to individuals ("I-egos") or even to social groups per se but rather to affects and haeceitties (moods and atmospheres/ ambiances) through which (and around which) identities (individual or group) can 
be productively mobilised. To navigate our way through these aesthetic and affective relationalities, where a multitude of different lines (some human, some not) intersect and transpose, we might greatly benefit from a schizoanalytical perspective that urges us to "transpierce" obstacles "instead of scaling them ... [to] bore holes in [conceptual] space instead of keeping it smooth" (Deleuze and Guattari 1988, 413). We need to move "through rather than across" space, to sense "a tangle of interlaced trails, continually ravelling here and unravelling there," if we want to find the "lines of relationships" along which individual beings or collectives "grow or issue forth," writes Ingold (2011, $71)$.

\section{REFERENCES}

Amrine, F. 2012. “Gilles Deleuze's Philosophy of Freedom.” Being Human 4: $29-32$.

Baudrillard, J. 1994. Simulacra and Simulation. Translated by S.-F. Glaser. New York: Semiotext(e).

Best, S., and D. Kellner. 1991. Postmodern Theory: Critical Interrogations. New York: Guildford.

Berardi, F. 2009. The Soul at Work: From Alienation to Autonomy. Los Angeles: Semiotext(e).

Brown, A. M., and W. Imarisha, eds. 2015. Octavia's Brood: Science Fiction from Social Justice Movements. San Francisco: AK Press.

Braidotti, R. 2006a. Transpositions: On Nomadic Ethics. Cambridge: Polity Press.

Braidotti, R. 2006b. "Affirming the Affirmative: On Nomadic Affectivity." Rhizomes: Cultural Studies in Emerging Knowledges 11/12. http://www.rhizomes.net/issue11/braidotti.html (accessed November 3, 2016).

Castells, M. 2010. Communication Power. Oxford: Oxford University Press.

Carstens, D. 2016. "The Anthropocene Crisis and Higher Education: A Fundamental Shift." South African Journal of Higher Education 30 (3): 255-73. https://doi.org/10.20853/30-3-650

Cipri, N. 2015. Review of Octavia's Brood: Science Fiction from Social Justice Movements, edited by M. Brown and W. Imarisha. Strange Horizons 2. http://www.strangehorizons.com/non-fiction/reviews/ octavias-brood-science-fiction-stories-from-social-justice-movements-edited-by-adrienne-mareebrown-and-walidah-imarisha/ (accessed November 3, 2016).

Coverley, M. 2010. Psychogeography. London: Pocket Essentials.

Deleuze, G. 1995. Negotiations, 1972-1990. Translated by M. Joughin. New York: Columbia University Press.

Deleuze, G. 2013. Cinema II: The Time Image. New York: Bloomsbury.

Deleuze, G., and F. Guattari. 1983. On the Line. Translated by J. Johnston. New York: Semiotext(e). 
Deleuze, G., and F. Guattari. 1988. A Thousand Plateaus: Capitalism and Schizophrenia. Translated by B. Massumi. London: Continuum.

Deleuze, G., and F. Guattari. 2009. What Is Philosophy? Translated by H. Tomlinson and G. Burchill. London: Verso.

Dolphijn, R. 2015. "A Matter of Life: Ecology in Spinoza, Deleuze and Meillassoux." YouTube video, 14:57, posted by Actual Virtual Journal, January 4, 2015. https://www.youtube.com/ watch? $=$ FaWmNDRDtm8 (accessed November 3, 2016).

Dunne, A. 2005. Hertzian Tales: Electronic Products, Aesthetic Experience, and Critical Design. Cambridge, MA: MIT Press.

Evans, C. 2003. Fashion at the Edge: Spectacle, Modernity, and Deathliness. New Haven: Yale University Press.

Fernández-Armesto, F. 2001. Civilisations. London: Pan Books.

Fintoni, L. 2016. "Complex Movements is the Detroit Collective Using Sci-Fi Storytelling to Empower Its Community." Fader, November 2. http://www.thefader.com/2016/11/02/complex-movementsdetroit-interview (accessed November 3, 2016).

Fisher, M. 2001. “Gothic Materialism.” Pli: The Warwick Philosophy Journal 12: 230-43.

Fisher, M. 2009. Capitalist Realism: Is There No Alternative? London: Zero Books.

Gaines, M., and A. Segade. 2008. “Tactical Collage.” In Wangechi Mutu: A Shady Promise, edited by D. Singleton, 145-46. Bologna: Damiani.

Guattari, F. 1984. Molecular Revolution: Psychiatry and Politics. Translated by R. Sheed. New York: Penguin.

Guattari, F. 1995. Chaosmosis: An Ethico-Aesthetic Paradigm. Translated by P. Bains and J. Pefanis. Paris: Power Institute.

Guattari, F. 2000. The Three Ecologies. Translated by P. Sutton and I. Pindar. London: Athlone Press.

Goodman, S. 2010. Sonic Warfare: Sound, Affect and the Ecology of Fear. Cambridge, MA: MIT Press.

Imarisha, W. 2015. "Rewriting the Future Using Science Fiction to Re-Envision Justice." Bitch Media, February 11. https://bitchmedia.org/article/rewriting-the-future-prison-abolition-science-fiction (accessed November 3, 2016).

Ingold, T. 2011. Being Alive: Essays on Movement, Knowledge and Description. New York: Routledge.

Lahoud, A., and E. Weisman. 2014. "Geo-Politics: Conflict and Resistance in the Anthropocene." $H K W$, November 14. https://www.hkw.de/en/programm/projekte/2014/anthropocene_campus/ anthropozaen_campus_opening_weekend/opening_weekend_geopolitics.php (accessed November $3,2016)$. 
Jameson, F. 2007. Archaeologies of the Future: The Desire Called Utopia and Other Science Fictions. London: Verso.

Jones, A. 2009. "The Next Mass Extinction: Human Evolution or Human Eradication." Journal of Cosmology 2: 316-33.

Kiley, B. 2015. "The Politicized Theater of Detroit-Based Collective Complex Movements." The Stranger, April 16. http://www.thestranger.com/blogs/slog/2015/04/16/22057405/the-politicized-theater-ofdetroit-based-collective-complex-movements (accessed November 3, 2016).

Kumar, K. 1995. “Apocalypse, Millennium and Utopia Today.” In Apocalypse Theory and the Ends of the World, edited by M. Bull, 200-24.Oxford: Blackwell.

Kroker, A. 1992. The Possessed Individual: Technology and Postmodernity. London: Macmillan Press. https://doi.org/10.1007/978-1-349-21818-9

Luckhurst, R. 2005. Science Fiction. Cambridge: Polity.

Mackay, R., and A. Avanessian. 2014. Accelerate: The Accelerationism Reader. Falmouth: Urbanomic Media.

Mohanty, C. T. 2003. Feminism Without Borders. Decolonising Theory, Practicing Solidarity. Durham: Duke University Press. https://doi.org/10.1215/9780822384649

Massumi, B. 2014. What Animals Teach Us about Politics. Durham: Duke University Press. https://doi. org/10.1215/9780822376057

Meek, M. 2016. "10 Film-Makers to Watch: Complex Movements." The Independent, March 22. http:// independent-magazine.org/2016/03/10-filmmakers-to-watch-complex-movements/ (accessed November 3, 2016).

Orphan Drift. 1995. Cyberpositive. London: Cabinet Press.

Palmer, C. 1999. "Galactic Empires and the Contemporary Extravaganza: Dan Simmons and Iain M. Banks.” Science Fiction Studies 26 (1): 73-90.

Parikka, J. 2015. The Anthrobscene. Minneapolis. The University of Minnesota Press.

Plant, S. 1992. The Most Radical Gesture: The Situationist International in a Postmodern Age. London: Routledge.

Ramey, J. 2012. The Hermetic Deleuze: Philosophy and Spiritual Ordeal. Durham: Duke University Press. https://doi.org/10.1215/9780822395249

Royle, N. 2003. The Uncanny. Manchester: Manchester University Press.

Sassen, S. 2014. Expulsions: Brutality and Complexity in the Global Economy. London: The Bellknap Press. https://doi.org/10.4159/9780674369818

Solnit, R. 2007. Storming the Gates of Paradise: Landscapes for Politics. Berkeley: University of California Press. 
Sterling, B. 1986. Preface to Mirrorshades: The Cyberpunk Anthology, edited by B. Sterling. London: Palladin.

Winterson, J. 2007. The Stone Gods. London: Penguin Books.

Žižek, S. 2011. Living in End Times. London: Verso. 